\title{
Listening Comprehension by using Video in Online Class through WhatsApp
}

\author{
Lusi Marleni ${ }^{\text {, }}$ Nurhidayah Sari ${ }^{\text {, }}$ Vitri Angraini Hardi 3
}

DOI: $10.35445 /$ alishlah.v13i1. 427

\begin{abstract}
Article Info
Abstract

Keywords:

Listening Comprehension

Video

Online Class

This research aims to determine whether there is an effect of using video as media on the students' listening comprehension in an online class in the academic year 2020/2021. This research is pre-experimental. It involved 24 students in class. The class was taught by using video as media as the treatment in the class. The data were analyzed quantitatively by using the Ttest formula. The result shows that the students listening comprehension in the post-test are higher than pre-test. The data analysis can be seen in many students who get a good score in the class by using video. It can be concluded that video in teaching listening comprehension in an online class is an influential media. As aresult, $T_{\text {count }}$ is 7,03 and $T_{\text {table }}$ is 1,68 . In this case, the average score is 72 . The use of video for listening comprehension is one of the alternative media in online class.
\end{abstract}

Kata Kunci:

Pemahaman Menyimak

Video

Kelas Online

\begin{abstract}
Abstrak
Penelitian ini bertujuan untuk mengetahui apakah ada pengaruh penggunaan video terhadap pemahaman menyimak siswa di kelas online tahun ajaran 2020/2021. Penelitian ini merupakan penelitian pra eksperimental yang melibatkan 24 siswa di kelas. Kelas ini diajar dengan menggunakan media Video sebagai perlakuan di kelas. Data dianalisis secara kuantitatif dengan menggunakan rumus T-test menunjukan hasil penelitian ini menunjukkan bahwa pemahaman menyimak siswa pada post test lebih tinggi dari pada pre test. Hal tersebut terlihat pada analisis data bahwa banyak siswa yang memperoleh nilai baik di kelas dengan menggunakan Video. Dapat disimpulkan bahwa penggunaan Video dalam pembelajaran pemahaman menyimak di kelas online merupakan media yang efektif. Hasilnya, Tcount adalah 7,03 dan Ttable adalah 1,68. Dalam hal ini nilai rata-rata siswa adalah 72. Penggunaan video pada pembelajaran pemahaman menyimak dapat menjadi alternatif media dalam pembelajaran di kelas online.
\end{abstract}

\section{INTRODUCTION}

One of the most commonly used skills for communication is listening comprehension, especially in English. It is considered the most difficult language skill to study (Gilakjani \& Sabouri, 2016). Many students cannot get the information in English ideally because they have a problem learning English, especially in listening comprehension (Marleni, 2016).

\footnotetext{
${ }^{1}$ Universitas Pahlawan Tuanku Tambusai, Riau, Indonesia Email: lusimarlenihz@gmail.com

${ }^{2}$ Universitas Pahlawan Tuanku Tambusai, Riau, Indonesia

Email: aie_nurhidayah@yahoo.com

3 Universitas Pahlawan Tuanku Tambusai, Riau, Indonesia

Email: vitrihardi@gmail.com
} 
In this era, a problem caused by Coronavirus or covid-19 gave effects of the learning process which must be stopped in the school. The government gave the information that the student must be studied at home, and the teacher must provide some assignments for the students. Automatically, in the teaching-learning process must have used online class as media, such as using: WhatsApp, YouTube, Zoom Application, Instagram, and moodle. Marleni and Asilestari (2018) state that one of the media that can be used in teaching English is Social media such as Facebook, Instagram, etc.

Based on the observation in listening class in the first semester of the English Language Education department of the University of PahlawanTuankuTambusai, many students can not catch the information in spoken English text well. When the teacher asked them to say something after the listening activity, they did not understand it. They did not express their information well. They also have a problem in concluding listening to the text. Based on the data, the students listening comprehension is still at a low level. There are three students in the poor grade. It is <55 score, in average three students is 52 score. Eighteen students in fair level, it is 55-64 score, in the average 18 students is 56-64. Three of the students in a good level are 65-75 score, and the average is 68 .

Using video as media in teaching English by sing the WhatsApp application is a good idea (Marleni et al., 2018). In this case, the video teaches listening comprehension by listening to the information through the video. Video can self-reflect, and it is widely recognized as the desirable learner attribute that can induce deep learning. Video is a device that uses a camera to record various activities: performance in an oral test and role-plays. Using video as media of learning can bring a good atmosphere to the students in learning English. Students will get an easy way to understand the information (Justsinta Sindi Alivi*, 2016). The use of video on students' listening comprehension in language learning offers several advantages: First, students can watch and see themselves and their fellow friends' performances. Second, teachers can use video to help students become better speakers of English. Besides, students have the opportunity to view the recording on video more than once (Gilakjani \& Sabouri, 2016)(Justsinta Sindi Alivi*, 2016).

A good technique in teaching can make students understand and enjoy learning. In this case, technology is essential. Nowadays, technology has a significant influence on learning teaching the educational field. One of them is media communication for getting information. People can easily access social media through smartphones (Justsinta Sindi Alivi*, 2016)(Sataloff et al., n.d.)

Many media can be used as media in the learning activity. Video is one media to deal with the students' problems in listening comprehension. Video is one of the suitable media that can be used. By video, the students can see the picture and listen to the audio. The students can easily analyze the mistakes, watching the video later. The statement can be used as a tool to record and correct students' listening comprehension. Therefore, students understand the information easily (Sulistyowati, 2010).

Media is one of the facilities to improve the learning activities. Because of the variety of media, it has different characteristics. (Megawati \& Astutik, 2019)Media are tools that the teacher uses in the teaching-learning process. The uses of media help the students master the material presented by the teachers more easily. Media can be a picture, video, action, or people. It can be concluded that using media with creativity will give effectiveness in the teaching and learning process. Media also can make the students interested in learning. By using good media, it can help the students to express their ideas.

WhatsApp is a social media application involving direct messaging and sharing media, including voice messages, videos, and photos. (Setyowati, 2019)WhatsApp in education is included educational technology that can be used as a tool or media communication in education development. WhatsApp is a messaging app that lets users text, chat, and share media, including voice messages and video, with individuals or groups. WhatsApp allows for accessible communication with people over a long distance. WhatsApp is available on relatively any device and is considered relatively safe 
and secure. The use of social networks has become popular in everyday communication. It is even used for collaborative learning, especially in language learning. Social network applications such as Facebook, Twitter, LinkedIn, and many others have been phenomenally popular in the communication world ( $\mathrm{Li}, 2017$ ).

WhatsApp allows users to use their Internet connection to send messages to each other. WhatsApp is like a chat program for mobile phones. Smartphones are becoming increasingly popular, and WhatsApp is available for almost all smartphones (Jasrial, 2017). Advantages of WhatsApp for teaching and learning are; 1) WhatsApp instant messaging facilitates online collaboration and cooperation between online students connected from school or home in blended mobile teachers. 2) WhatsApp is a free application that is easy to use. 3) Group connected to WhatsApp instants messaging can share learning objects easily through status, audio, video, comment, texting, and messaging. Discuss are related to the course content taught in class. 4) WhatsApp allows students to create a class publication and thereby publishing their work in the group. 5) Information and knowledge are easily constructed and shared. Therefore, it is important to investigate video as media on the students' listening comprehension in the online class.

Using video as media in listening class has been studied in listening class. (Ali \& Shahid, 2017) took a study that shows the increase of students' listening comprehension by using video as media. They used video podcasts as media in the class. The results show an ANCOVA analysis showing the video-podcast group significantly increased the students' listening comprehension on the post-test. It implies that video podcasts enhance EFL learners' listening comprehension as the resource of learning. (Sarani et al., 2014) also researched using video as media in listening comprehension. The result shows that teaching listening through video-based tasks significantly affected the students' listening comprehension. Those researches was taken in the face-to-face class. There is no research on investigating the effect of video on the students' listening comprehension in an online class through WhatsApp. Therefore, this research is essential to examine the impact of video as media in an online course through WhatsApp.

\section{METHODS}

This research connects a pre-experimental investigation plan, including pre-test and post-test, to degree students' listening comprehension. The study was conducted at the University of Pahlawan Tuanku Tambusai, particularly during the first year of the English Language Education Department. It was one lesson as a test. The research was conducted in the first semester of the English Language Education Study Program of the University of Pahlawan Tuanku Tambusai. It is located on Jl. Tuanku Tambusai No.23 Bangkinang-Kampar. This research was conducted from September 2020February 2021. The researcher used to test as the instruments. The researcher gave a pre-test before doing the research, then experimented by teaching in the online class through WhatsApp. The last, the researcher did a post-test, then analyze the data. The data were analyzed statistically by the $t$ table formula (Sugiyono, 2010).

\section{FINDINGS AND DISCUSSION}

This research was conducted from September 2020 until January 2021, during the first year of the English Language Education Department of the University of Pahlawan Tuanku Tambusai. This research was experimental research by using video as media in listening comprehension class. This research aims to obtain the students' listening comprehension data after learning online by using video as media. 


\section{Students' Speaking Skill}

a. Pre-Test Score

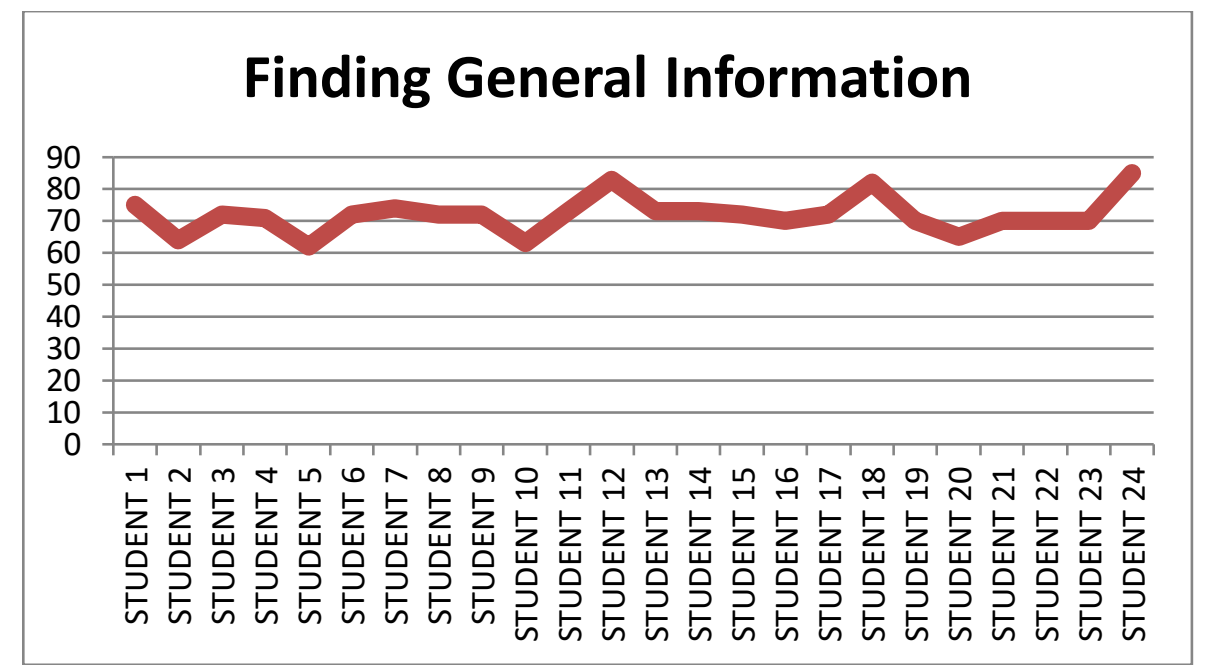

Figure 1. The Students Pre-Test Score of Finding General Information

Based on the figure above, only three students got scores $>80$, which is the class's higher score. The lowest score is 62.5 students got $<65$. It means they got the lower score in this indicator. Meanwhile, 16 students got 70-75. It means the average student score is 72 for this indicator. It could be concluded that almost all of the students in an insufficient level of general information.

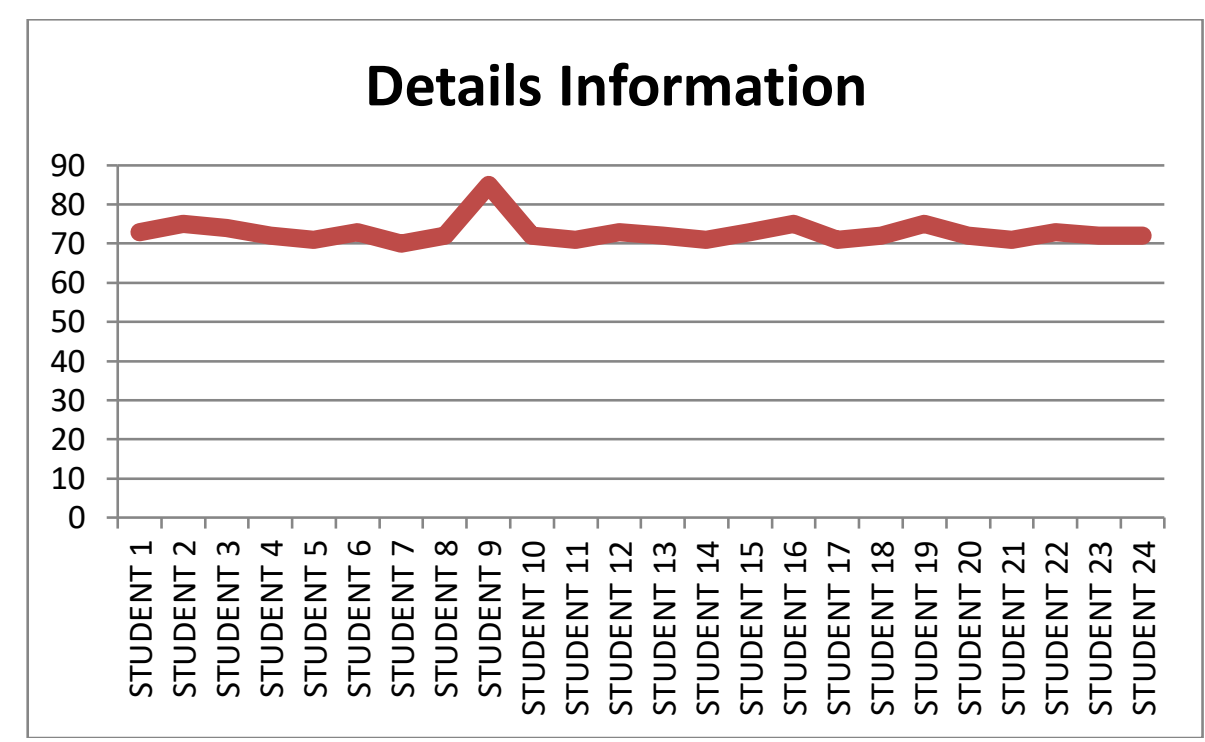

Figure 2. The Students Pre-Test Score of Details Information

Based on figure 2 above, only one student who got 85 was the higher score in the class. Meanwhile, 23 students got 70-75. It means the students got the average score in this indicator. It could be concluded that the students in an insufficient level of details information. 


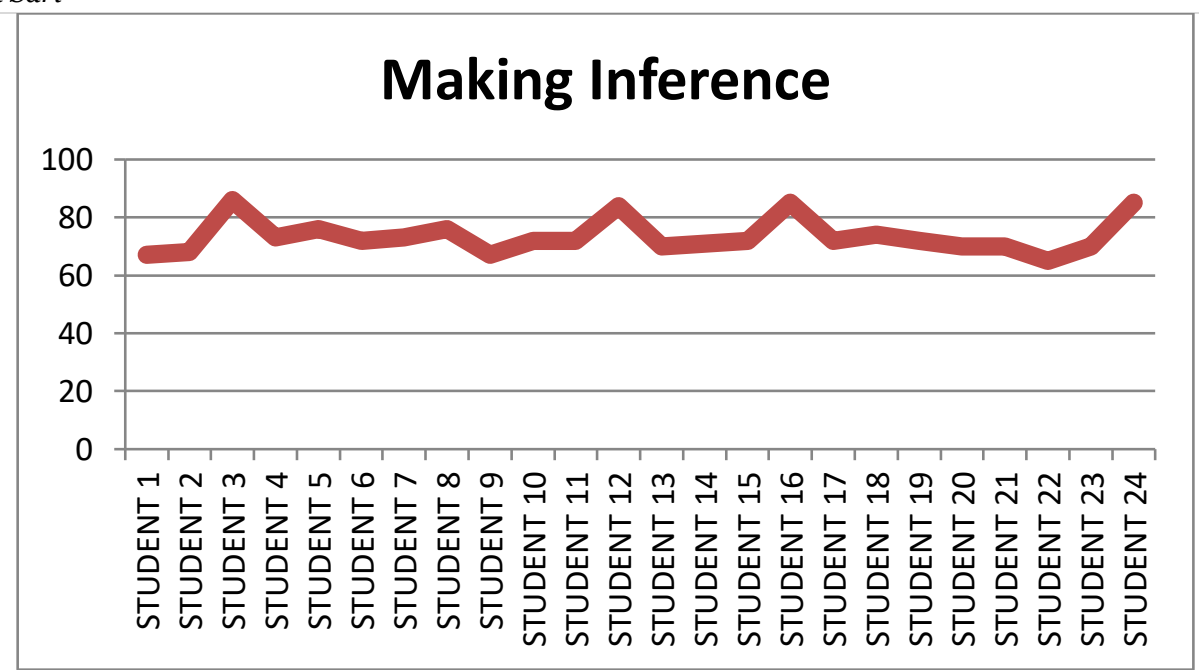

\section{Figure 3. The Students Pre-Test Score of Making inference}

Based on figure 3 above, only four students got $>85$ which was the highest score in the class. Meanwhile, 20 students got 70-76. It means the average of the students got a score in this indicator. It could be concluded that most of the students in a good level of making the inference.

Table 1. The Recapitulation of the Pre-test Result

\begin{tabular}{ll}
\hline $\begin{array}{l}\text { Listening } \\
\text { Comprehension } \\
\text { Indicators }\end{array}$ & $\begin{array}{l}\text { Pre-Test Indicator } \\
\text { Score }\end{array}$ \\
\hline General Topic & \\
Details & 70 \\
information & 73 \\
Making inference & 68 \\
\hline
\end{tabular}

Based on the table above, the higher indicator is detailed information, which is the students got a total score of 73 in the indicator. The lowest total score is 68 . There was making an inference. It could be concluded that in listening comprehension in the pre-test, the students were good at finding detailed information. But, making an inference is still bad. It is also finding general information, the students still stuttering.

b. Post-Test Score

Based on the post-test data. The analysis is described below:

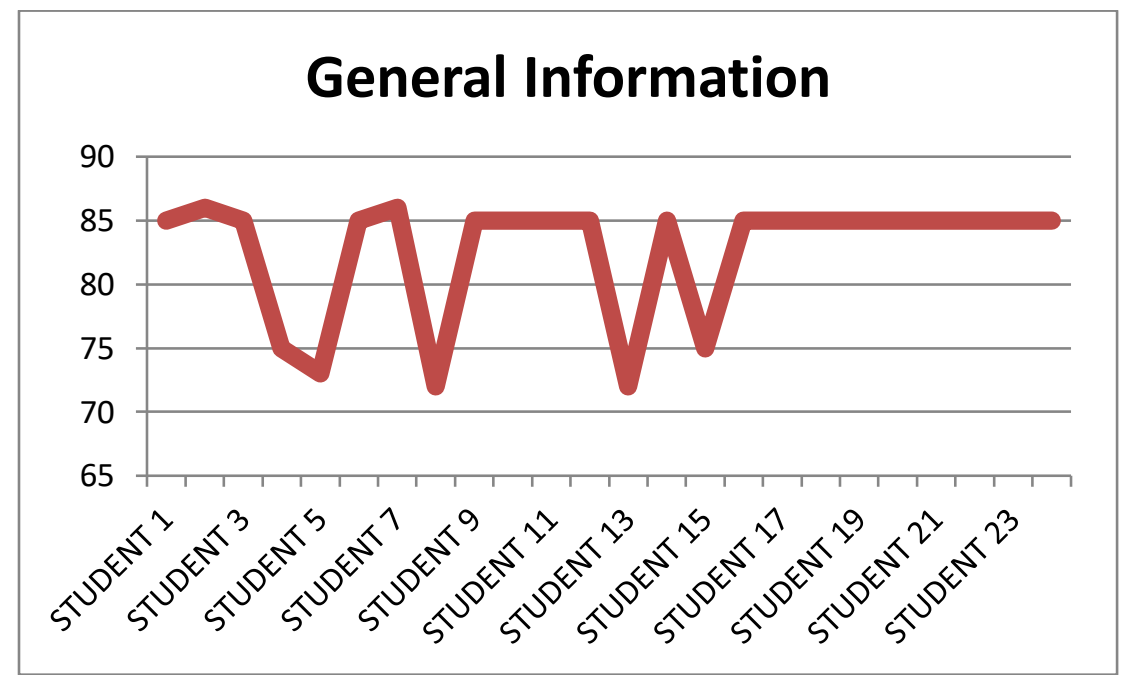

Figure 4. The Students Post-Test Score of general information 
Based on the figure above, 19 students got the higher score in the class. The higher score is $>85$. The students got a very good score. Meanwhile, five students got 70-75 scores. There were got a good score. It could be concluded that using video gave the effect of student ability in identifying the general information of a spoken text. The student is outstanding level in determining the available information.

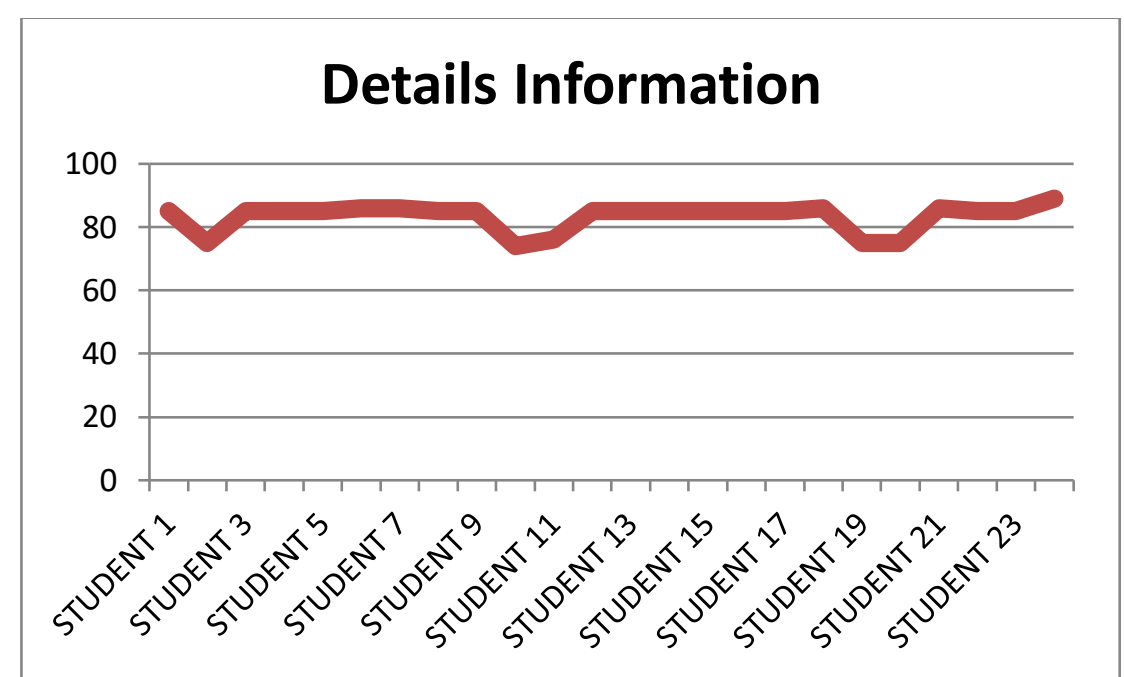

Figure 5. The Students Post-Test Score of Details Information

Based on the figure above, one student got the highest score in the class. The higher score is 89 . The students got an excellent score. Meanwhile, 18 students got $>80$ scores. It is also higher than a very good score. Five students got $>70$ scores. No student got $<70$. It could be concluded that using video in listening comprehension through online class gave the effect of student ability in finding detailed information-almost all of the students are very good.

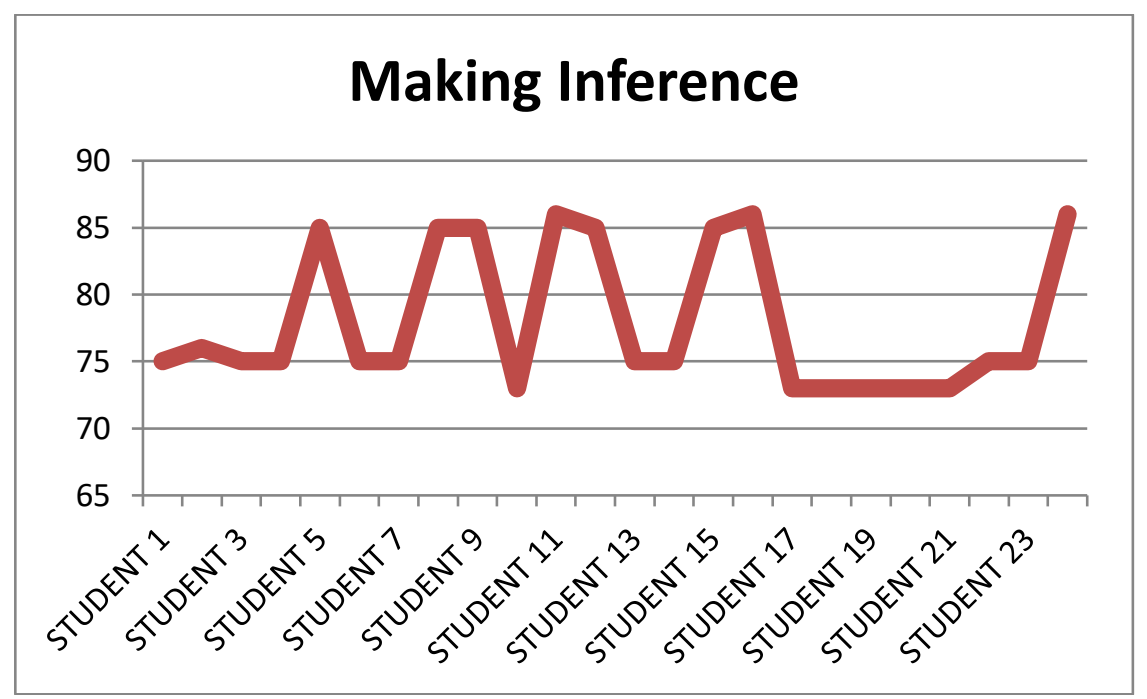

Figure 6. The Students Post-Test Score of Comprehension

Based on the figure above, eight students got a high score in the class. The score is $>85$. The students got a very good score. Meanwhile, 16 students got $>75$. There were got a good score. It could be concluded that the students' listening comprehension by using video in online class gave the students the ability to make inferences of the spoken text.

Table. 2. Recapitulation of Post Test

\begin{tabular}{lr}
\hline \multicolumn{1}{c}{ Listening Comprehension } & \multicolumn{2}{c}{ Pre-Test } \\
Indicators & Indicator Score \\
\hline General Topic & 91 \\
Details information & 92 \\
Making inference & 80 \\
\hline
\end{tabular}


The higher indicator identifies general information, finds detailed information, and makes inferences based on the table above. Which are the students got total score each indicator is 91, 92 and 80 . It could be concluded that the students' ability to identify general information is very good by using video in an online class. So that, the student ability in finding details information in very good level. It is also of making an inference. The student is not stuttering anymore. The students' performance in making an inference is a good level.

\section{The Data Analysis}

a. The Categorization Pre-Test scores

After categorization of the listening comprehension scores of the experimental group from the formula, the frequency and percentage were received, for "poor" category, it can be seen that there was 3 or $12.5 \%$, for a "fair" was 18 or $75 \%$ and for "good" category was 3 or $12.5 \%$ and for a "very good" and "excellent" category was o or $0 \%$. It can be seen for the students listening comprehension in the pre-test scores on the fair level. It is described in the following table:

Table 3. Pre-Test Categorization Result

\begin{tabular}{crr}
\hline & Frequency & Percent \\
\hline Poor & 3 & 12,5 \\
Fair & 18 & 75 \\
good & 3 & 12,5 \\
Total & 24 & 100,0 \\
\hline
\end{tabular}

b. The Categorization of Post-Test scores

The result of the post-test scores control group showed that the frequency and percentage of "fair" category was 19 or $79 \%$ and for the "good" category was 5 or $21 \%$ and for a "poor", "very good" and "excellent" category was 0 or $0 \%$. It is showed in the following figure:

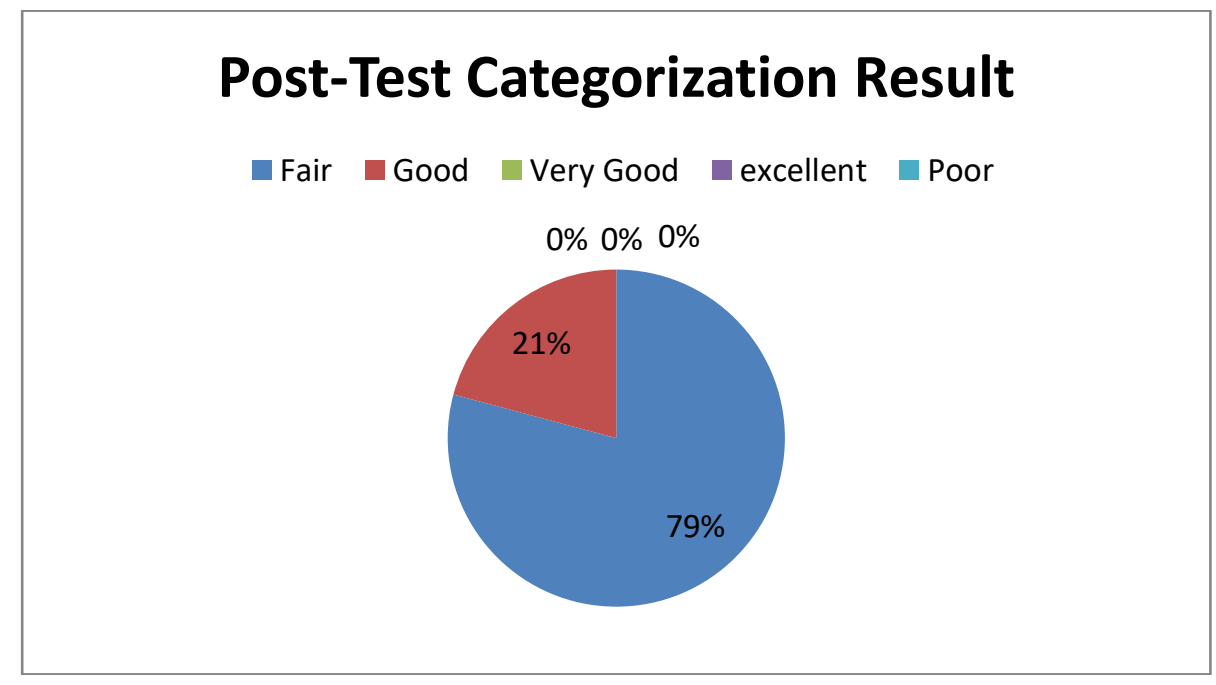

Figure 7. The Categorization of Control Group's Post-Test scores

Based on the table above, it shows that there was a better score after doing the research. It can be seen from the average of 9. It can be concluded that there was a positive effect in using video as media in Online Listening Class at the second semester of English Language Education Study Program of University of Pahlawan Tuanku Tambusai than pre-test. The post-test score is higher than the pre-test.

\section{Validity and Reliability of the Test}

\section{a. Validity}

The item analysis calculation on the pre and post-test did manually by using the Product Moment Formula. Based on an interpretation of the validity item, the summary of the results, the calculation of validity of the pre-test and post-test that has been tested can be seen on the following table: 
Table 4. Trial Result of Validity Pre-Test

\begin{tabular}{lcc}
\hline \multicolumn{1}{c}{ Assessment Aspects } & Score & Criteria \\
\hline General Information $=\mathrm{x} 1$ & 0,87 & Valid \\
Details Information $=\mathrm{x} 2$ & 0,41 & Valid \\
Inference $=\mathrm{x} 5$ & 0,53 & Valid \\
\hline
\end{tabular}

Table 5. Trial Result of Validity Post-Test

\begin{tabular}{lcc}
\hline \multicolumn{1}{c}{ Assessment Aspects } & Score & Criteria \\
\hline General Information $=\mathrm{x} 1$ & 0,42 & Valid \\
Details Information $=\mathrm{x} 2$ & 0,62 & Valid \\
Inference $=\mathrm{x} 5$ & 0,58 & Valid \\
\hline
\end{tabular}

b. Reliability

To calculate the reliability of the pre-test and post-test, the researcher used Alpha Cronbach Formula. The summary of the calculation level of the result instrument reliability can be seen based on the table below:

Table 6. The Result of Reliability

\begin{tabular}{llcc}
\hline No & Question & $\boldsymbol{r}_{\mathbf{1 1}}$ & Interpretation \\
\hline 1. & Pre-Test & $\mathbf{1 , 1 8}$ & Very High \\
2. & Post-Test & 0,44 & Enough \\
\hline
\end{tabular}

Based on table 6 above, for pre-test $r_{11}$ is 1,18 , it includes very high interpretation. For posttest $r_{11}$ is 0,44 , it includes enough interpretation. It means the result of reliability is reliable.

\section{Inferential Analysis}

The technique of data analysis that was conducted in this research is a t-test. This test is performed to determine a significant difference before and after giving the treatment from the researcher. The value of pre-test and post-test was analyzed statistically by using normality test, homogeneity test, and t-test.

\section{a. Test Result Normality of Pre-test and Post-test}

The data analyzed in this normality test was Pre-test and Post-test value data in the pre-test and post-test. The Normality test aimed to determine whether the data of each class is normally distributed or not. In this research, the researcher use Chi quadrat, where $H_{0=}$ not normal distribution and $H_{a=}$ Normal distribution. One of the assumptions that must be met before testing the homogeneity of the pre-test variance should be normally distributed. The result of the normality test was summarized in the following table:

Table 7.Test Result Normality of Pre-test and Post-test

\begin{tabular}{lccc}
\hline \multicolumn{1}{c}{ Class } & $\boldsymbol{x}^{\mathbf{2}}$ count & $\boldsymbol{x}^{\mathbf{2}}$ table & Summarized \\
\hline Pre-test Experiment & $-9,92$ & \multirow{2}{*}{11,07} & Normal Distribution \\
Post-test Experiment & 10,23 & & Normal Distribution \\
\hline
\end{tabular}

Based on the table above, it can be seen that $x^{2}$ count lower than $x^{2}$ table $\left(x^{2}\right.$ count $<$ $x^{2}$ table). So that, $H_{0}$ is accepted and $H_{a}$ is rejected. It means that the data of the post-test and pretest is normally distributed.

b. Homogeneity Test of Variance of Pre-Test and Post-Test

The homogeneity Test of Variance has done to know whether the pre-and post-tests have the same variance. In determining whether the pre-test data and post-test had homogeneous by 
comparing $F_{\text {count }}$ and $F_{\text {table }}$, where the value of $F_{\text {count }}$ homogeneous by comparing $F_{\text {count }}$ and $F_{\text {table }}$, where the value of $F_{\text {count }}$ obtained by comparing the largest variance value with the smallest variance have. The result can be summarized in the following table:

Table 8. Homogeneity Test of Variance of Pre-Test and Post-Test

\begin{tabular}{rcccccc}
\hline Class & Variance & $\mathbf{N}$ & $\mathbf{F}_{\text {count }}$ & $\mathbf{F}_{\text {table }}$ & Explanation & Summarized \\
\hline Post-test & 19,94 & & & & & \\
Pre-test & 16,17 & 24 & 1,23 & 2,05 & $F_{\text {count }}<F_{\text {table }}$ & Homogeneous \\
\hline
\end{tabular}

Based on the table above and processed data of researchers, it can be seen that $F_{\text {count }}$ of both classes is lower than $F_{\text {table }}\left(F_{\text {count }}<F_{\text {table }}\right)$. So $H_{0}$ is accepted and $H_{a}$ is rejected, it means that the pre-test and post-test data were homogeneous.

c. The Average Score

Based on data calculations in pre-test and post-test, the results were distributed normally and had a homogeneous variance. Then the average test used the t-test. The results of the average test calculation (t-test) are summarized in the following table:

Table 9. The Average of Post-Test Value in the pre-test and post-test

\begin{tabular}{lccccc}
\hline \multicolumn{1}{c}{ Test } & $\mathbf{N}$ & Average & $\boldsymbol{t}_{\text {count }}$ & $\boldsymbol{t}_{\text {table }}$ & Summarized \\
\hline Post test & 24 & 72 & 7,03 & 1,68 & \multirow{2}{*}{$t_{\text {hitung }}>t_{\text {tabel }}$} \\
Pre-test & 24 & 63 & 7,03 & \\
\hline
\end{tabular}

Based on the table above from the data researcher, it is obtained $\boldsymbol{t}_{\text {count }}=7,03$. Degrees of freedom in the $t$ distribution list was $n_{1}+n_{2}-2=46$ with the degree of freedom 46 , so that, obtained $\boldsymbol{t}_{\text {table }}=1,68$. Then, $\boldsymbol{t}_{\text {count }}>\boldsymbol{t}_{\text {table }}(7,03>1,68)$. So, it can be concluded that $H_{a}$ is accepted and $H_{0}$ is rejected. There are significant differences between pre-test and post-test outcomes after giving the treatment.

It can be concluded that there are significant differences between pre-test and post-test. Therefore, it was found that there was a significant effect of using video as media on students' listening comprehension in Online classes.

Based on the data of post-test obtained, after getting the treatment conducted, there is a difference between the learning outcomes in listening comprehension by video as media in an online class with the students result in the pre-test. The average outcome of the experimental class is 72 , and the control class is 63 . It can be seen from the graphic below:

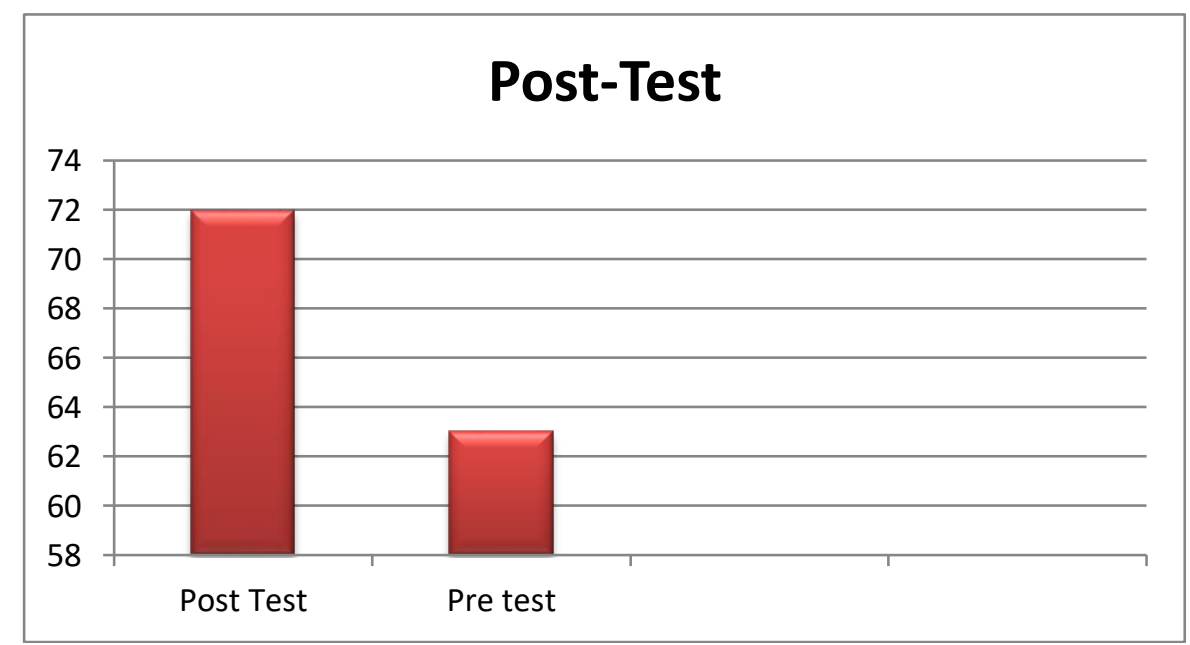

Figure 8. The Comparison of Average Value

Inferential analysis got from $t_{\text {count }}=7,03$ and $t_{\text {table }}=1,68$ where $\alpha=0,05$. Based on test one side, it is clear that $t_{\text {count }}>t_{\text {table }}$, so that $H_{a}$ is rejected and $H_{0}$ is accepted. It means that there is a 
difference between the average learning outcomes of the post-test and the average learning outcomes of a pre-test. It can be concluded that there are significant differences between outcomes of post-test by using video in online class than the pre-test.

In analyzing supporting data, the hypothesis acceptable, states that there is a positive effect by using video as media in the online class, especially in listening comprehension at the second semester of English Language Education of University of Pahlawan Tuanku Tambusai.

There was a significant difference between the students' listening comprehension who was taught using video in the online class and the students' listening comprehension taught by other media. It can be concluded that there was a positive effect in teaching listening comprehension by using video as a media in the online class.

It is in line with (Sarani et al., 2014), which found that teaching listening by using video showed the students' listening comprehension effectiveness. It improved the students' skill in identifying the topic of the spoken text, making inferences, and finding the specific information in the video. The students stated that the task helped them to have good listening comprehension with a difference atmosphere. Using video as media in the class improved the students' listening comprehension.

The researcher collected the data to answer the research question successfully. The explanation for the research question can be clarified according to data gained from the pre-test and post-test. It was supported by the fact that the students' listening comprehension before and after implementing video in an online class was different. The average of the students listening comprehension before implementing video as media was 63 and after implementing it was 72, the total of student number was 24 students. By using video gives an effect on students' listening comprehension. Related to (Ali \& Shahid, 2017), the students get a better score after getting the treatments by using video on listening class.

The effect was proved by the students' score percentage in the post-test. The result was obtained the average score of the experimental class was 72, which was higher than the control class, 63. The reliability result shows pre-test $r_{11}$ is 1,18 it is included very high interpretation and the reliability of post-test $r_{11}$ is 0,44 it includes enough interpretation. It means the test are reliable. The result of $\boldsymbol{t}_{\text {count }}$ is 7,03. Degrees of freedom in the $t$ distribution list was $n_{1}+n_{2}-2=46$ with the degree of freedom 46 , so that, obtained $\boldsymbol{t}_{\text {table }}=1,68$. Then, $\boldsymbol{t}_{\text {count }}>\boldsymbol{t}_{\text {table }}(7,03>1,68)$. It can be concluded that $H_{a}$ is accepted and $H_{0}$ is rejected. There are significant differences between pre-test and post-test outcomes after giving the treatment. Listening comprehension by using video as a media in online class makes the students' enjoy and better in English. They showed their excitement to the lesson because nowadays students can use the technology in learning English. Teaching and learning activity in online class runs effectively because the researcher used WhatsApp as media online that the students always use to chatting and learning during the condition of virus or corona.

\section{CONCLUSION}

Based on data analysis and discussion, it can be concluded that video positively affected students' listening comprehension in the online class. After implementing the research, the students listening comprehension in the post-test is higher than pre-test. It can be seen in the data analysis are many students get a good score in the class by using video. As a result, $T_{\text {count }}$ is 7,03 and $T_{\text {table }}$ is 1,68 concluded that video is an effective media for teaching listening comprehension. This research theoretically implicates that using video as media in an online class through WhatsApp affects the students' listening comprehension. Practically, this research can be considered by an English teacher in using video as media in the online class. The limitation of this research is on the bad network during the application of video as media in an online class through WhatsApp. The researcher needed to give more time for the students to access the video and doing the exercises. Therefore, the next researcher needs to ensure the internet connection well before doing the research. 


\section{ACKNOWLEDGEMENT}

Grateful thanks to the University of Pahlawan Tuanku Tambusaifor valuable contribution and funding of this research. Therefore, this research could be taken in the academic year 2020/2021.

\section{REFERENCES}

Ali, Z., \& Shahid, H. (2017). Effects Of Video-Podcasts On Listening Comprehension Of Saudi Efl Learners European Journal Of English Language Teaching Effects Of Video-Podcasts On Listening Comprehension Of Saudi Efl Learners. 2(August 2018), 169-194. https://doi.org/10.5281/zenodo.891143

Gilakjani, A. P., \& Sabouri, N. B. (2016). The Significance of Listening Comprehension in English Language Teaching. Theory and Practice in Language Studies, 6(8), 1670. https://doi.org/10.17507/tpls.0608.22

Jasrial, D. (2017). Utilizing whatsapp application for teaching english language : why and how ? $151-157$.

Justsinta Sindi Alivi*, S. (2016). Obtaining Listening Comprehension By Using Video Materials Perolehan Pemahaman Mendengarkan dengan Menggunakan Materi Video Justsinta Sindi Alivi* $^{*}$ Suharyono**. Exposure Journal ${ }^{* *}$. https://www.researchgate.net/publication/322066835_OBTAINING_LISTENING_COMPR EHENSION_BY_USING_VIDEO_MATERIALS

Li, V. (2017). Social Media in English Language Teaching and Learning. June. https://doi.org/10.18178/ijlt.3.2.148-153

Marleni, L. (2016). Jurnal paud tambusai. Jurnal PAUD Tambusai, 2(2), 36-42.

Marleni, L., Asilestari, P., Pahlawan, U., \& Tambusai, T. (2018). the Effect of Using Social Media : Whatsapp Toward the. Journal of English Language and Education, 3(2), 1-16.

Megawati, F., \& Astutik, Y. (2019). EFL Learning Media: Perspective on E-Learning through Google Classroom. April. https://doi.org/10.4108/eai.7-12-2018.2281768

Sarani, A., Zare Behtash, E., \& Nezhad Arani, S. (2014). The Effect of Video-Based Tasks in Listening Comprehension of Iranian Pre-intermediate EFL Learners. Los Efectos de Las Actividades Basadas En Videos En La Comprensión Auditiva de Los Estudiantes Iraníes de Inglés Intermedio, 8(8), 29-47. https://doi.org/10.26817/16925777.112

Sataloff, R. T., Johns, M. M., \& Kost, K. M. (n.d.). Using Video Materials as a Teaching Strategy for Listening Comprehension.

Setyowati, Y. (2019). Let's Listen Through WhatsApp: An energizing listening exercise in EFL Class. Journal of Physics: Conference Series, 1179(1). https://doi.org/10.1088/1742$6596 / 1179 / 1 / 012052$

Sulistyowati, T. (2010). the Impact of Teaching Listening Comprehension By Audio Video and Audio Picture Aids on the Third Semester Students 'Listening Proficiencies of English Education Department Students of Muria Kudus University in the Academic Year 2009 / 201O. 1-21. 